\title{
An Appraisal of Critical Highlights of the United Nations Environment Programme Report (UNEP) on the Environmental Assessment of Ogoni Land, The Setting Up of the Hydrocarbon Remediation Project (HYPREP) by the Federal Government of Nigeria, Its Operations and Recommended Pathways Towards Creating a Sustainable Environment and Development in Ogoni Land
}

\author{
SYLVANUS, ABILA Ph.D \\ Senior Lecturer and Head of Department, Private and Property Law, Faculty of Law Niger Delta University, \\ Wilberforce Island, Bayelsa State, Nigeria
}

\begin{abstract}
The paper carries out an appraisal of some critical highlights of the United Nations Environment Programme Report (UNEP) on the environmental assessment of Ogoni land, the setting up of the Hydrocarbon Remediation Project (HYPREP) by the Federal Government of Nigeria, its operations and recommended pathways towards creating a sustainable environment and development in Ogoni land. In achieving its aim, this paper adopts an admixture of the historical, comparative, empirical, the law and development approaches, in relevant areas. The paper ends with a conclusion and set of recommendations.
\end{abstract}

Keywords: Appraisal, United Nations Environmental Programme Report (UNEP), Ogoni land, Highlights, Hydrocarbon Remediation Project (HYPREP), Recommendations, Sustainable, Environmental assessment. DOI: $10.7176 / \mathrm{JEES} / 9-8-05$

Publication date: August $31^{\text {st }} 2019$

\subsection{BACKGROUND:}

According to the United Nations Environment Programme Report (UNEP), ${ }^{1}$ Ogoni land is a region covering some $1,000 \mathrm{~km} 2$ in the south-east of the Niger Delta basin. It has a population of close to 832,000 , according to the 2006 National Census, consisting mainly of the Ogoni people. The region is divided administratively into four local government areas: Eleme, Gokana, Khana, and Tai. Traditionally the area is formed by six kingdoms (Babbe, Eleme, Gokana, Ken-Khana, Nyo-Khana and Tai) with His Majesty King Godwin N.K. Gininwa as the area's Paramount Ruler.

\subsection{INTRODUCTION:}

While to the outside world, the communities of Ogoni land may appear similar, they have distinctive differences, including traditional institutional structures, languages and cultural features it is also important to know that; In the matter of the: Communication 155/96 the Social and Economic Rights Action Center Vs. the Center for Economic Social Rights/Nigeria, the African Commission on Human and Peoples' Rights, it was held that the Ogoni ethnic group of the Niger Delta region of Nigeria constitutes a 'people' within the contemplation of the African Charter on Human and Peoples' Rights, and therefore entitled to the protection and enjoyment of rights in their customary land and natural resources as provided under Article 21 of the African Charter. ${ }^{2}$ It is important to note from the onset, however, that the Royal Swedish Academy of Sciences had described the Niger Delta region of Nigeria where the Ogonis, (as an ethnic nationality), inhabit, amongst others, as the richest part of Nigeria in terms of natural resources. According to it, the area is known to have large oil and gas deposits, as well as extensive forests, good agricultural land with abundant fish resources etc. Despite the tremendous natural and human resources base, the said region's potential for sustainable development, appears to have remained unfulfilled and its future threatened by environmental degradation and deteriorating socio-economic conditions which were not effectively addressed by past/present policies and actions of the Federal Government Republic of Nigeria. Fifty [now about 60] years of oil/gas extraction do not appear to have brought significant benefits to the region. ${ }^{3}$ The Late Ken Saro-Wiwa, captured the adverse environmental effects of oil mineral exploration in Ogoni land particularly and in Niger Delta Region, in general, before his death, several years ago, for example, in the following

\footnotetext{
${ }^{1}$ See pages 22-24 of the report.

2 See further also Compilation of Decisions on Communications of the African Commission on Human and People' Rights, Extracted from the Commission's Activity Reports 1994 - 1999, Third Printing 2000, Institute for Human Rights and Development. See also Resolution on the Western Sahara (Thirteen Activity Report of the African Commission $1999-2000$, ACHPR/RTP/13 ${ }^{\text {th }}$, Annex V.

${ }^{3}$ Moff, D and Linden, O. "Journal of the Human Environment" The Royal Swedish Academy of Science, Vol. 24 (7-8), 1995
} 
words:

"Drilling of crude oil began in Ogoni land some thirty five years ago, making it one of the earliest areas from which crude oil was produced in Nigeria. The country's first oil refinery is in Ogoni land, at Eleme. So is, the Onne fertilizer plant, NAFCON. Since 1958, the contribution of crude oil to the national income has grown in leaps and bounds. Today, it contributes over 90\% of the country's export earnings. At the same time, the impact of oil production on the environment of this predominantly rural area has grown extensively. Not only have large tracts of farm land and fishing water been lost to drilling, but also the pollution arising from accident spillage of crude oil has destroyed marine life and made many hectares of farmland unsuitable for cultivation. The reckless dumping of usually toxic by-products of oil drilling and refinery, often in fresh water used for drinking, fishing and other household activities. On the other hand, the percolation of wastes from the oil industry into the soil contaminates ground water. At the same time, gas flaring in the vicinity of human dwellings and high-pressure oil pipelines forming a mesh across farmlands, have been conducive to acid rain, deforestation and destruction of wildlife. The international petrochemical giant, Shell dominates operations in Ogoni land as it does the entire Nigerian petroleum industry. The company's environmental record in developing countries is controversial, as was demonstrated by a Channel Four documentary, 'Heat of the Moment' shown in Britain in the autumn of 1992. ${ }^{1}$ The Ogoni land and its indigenous peoples gained international recognition following their plights occasioned by the continued environmental degradation in the area over the years coupled with the internationalization of the struggles protests/activities of the late Ken Saro-Wiwa, amongst others over the environmental conditions in Ogoni land led to eventual execution of Ken Saro-Wiwa, who to a large extent, dominated the struggle against the environmental problems occasioned by the activities of multi-national oil companies and the deprivation and poverty foisted on Ogoni land by the Nigerian domestic legal regime governing oil/gas production and distribution of the wealth therefrom. Following the intensity of the struggle, the late Ken Saro-Wiwa and nine other persons (operating under the auspices of the movement of the survival of the Ogoni people [MOSOP]) were arrested, tried by a tribunal and sentenced to death by the late maximum Nigerian military dictator - Gen. Sani Abacha. Instead of abating, however, the struggle for a fair Nigeria oil wealth and protests against environmental degradation appears to have gained more momentum. ${ }^{2}$ It was upon the above background that led to the United Nations Environment Programme to undertake the environmental assessment of Ogoni land calumniating to the setting up of the hydrocarbon remediation project (HYPREP) by the Federal Government of Nigeria towards creating a sustainable environment and development in Ogoni land in Nigeria. We shall now commence to examine some critical provisions dealing with the background and the terms of reference of the United Nations environmental programme report (UNEP) on Ogoni land with a focus on the status of UNEP, the background of its activities in Ogoni land, its terms of reference, the methodology adopted by it, challenges faced by it, its findings on: contaminated soil and groundwater, vegetation, aquatic, public health, institutional issues, oil industry practices etc.

\subsection{The United Nations Environmental Programme Report (UNEP) On the Ogoni Land And Its} Environment Of Nigeria.

The United Nations environmental programme (UNEP), an agency of the United Nations promotes environmentally sound practices globally and in its own activities using vegetable-based inks and other ecofriendly practices and operates policy aims to direct at reducing UNEP's carbon footprint. ${ }^{3}$

\subsection{The Background To The Activities Of UNEP In Ogoni Land}

In the words of Achim Steiner, the United Nations Under-Secretary-General and the Executive Director of the United Nations Environment Programme who wrote the forward to the scientific investigation of the environmental degradation in Ogoni land, at the time:

a. The history of oil exploration and production in Ogoni land [as being] a long, complex and often painful one that to date has become seemingly intractable in terms of its resolution and future direction.

b. It is also a history that has put people and politics and the oil industry at loggerheads rendering a landscape characterized by a lack of trust, paralysis and blame, set against a worsening situation for the communities concerned.

c. The reality is that decades of negotiations, initiatives and protests have ultimately failed to deliver a solution

\footnotetext{
${ }^{1}$ Quoted in Odje, A.M: The Challenges of True Federalism and Resource Control in Nigeria (Benin, Quadro Impressions Limited, 2002) P. 514

2 The Guardian Editorial 23 August 2015, p. 8. Reference hereby made to the emergence of The Movement for the Survival of the Ijaw Ethnic Nationality and the Egbesu Movement, The Aleibiri Resolution of 1997, The Egbesu Confrontations, The Emergence of the Ijaw Youths Council and the Kaiama Declaration, and The Asari Dokubo Rebellion and Re-Emergence of the Niger Delta Peoples Volunteer force. Further details see Abila, Sylvanus, Ph.D: "Historical and Philosophical Foundation of Minority Rights Movements in Niger Delta". Essays in honour of Justice Kate Abiri, Malthouse Press Ltd, Lagos, chapter 11, pp. 175-210.

${ }^{3}$ See the United Nations Environment Programme. (C) 2011, United Nations Environment Programme. ISBN: 978-92-807-3130-9, Job No.: DEP/1337/GE. United Nations Environment Programme, p. 2.
} 
that meets the expectations and responsibilities of all sides.

d. In an attempt to navigate from stalemate to action, the Government of Nigeria, in consultation with many of the relevant actors, invited UNEP to consider undertaking an assessment of oil pollution in Ogoni land. UNEP has acquired an international reputation for assembling expert teams, coordinating demanding assessments and bringing scientific and empirical evidence to policymakers. UNEP initially consulted with a wide range stakeholders and the United Nations Country Team in Nigeria in order to consider the scope and indeed the feasibility of the assessment. ${ }^{1}$

\subsection{Terms Of Reference Gleaned From The Executive Summary}

i. For the first time, the report presented a systematic and scientific evidence made available in the public arena on the nature, extent and impacts of oil contamination in Ogoni land.

ii. The report also provided clear operational guidelines as to how that legacy can be addressed. The oil industry has been a key sector of the Nigerian economy for over 50 years. But many Nigerians have paid a high price, as the assessment underlines.

iii. The findings in the report were made to catalyze not only significant environmental and social improvements in the region but a strategic policy on how the oil industry should function in a way that truly benefits the lives and livelihoods of these communities now and in the future. ${ }^{2}$

\subsection{The Methodology Adopted And Challenges Faced By United Nations Environmental Programme} In the process of conducting the study, "the UNEP was confronted with unique challenges of: lack of trust between actors; political tensions between communities; regional and national government; gaining access to Ogoni land; security considerations and technical and logistical challenges. Despite imperfect conditions, UNEP in the end agreed to undertake the study as it represented the only tangible option for possibly breaking the decades of deadlock while providing the government and stakeholders with a potential foundation upon which trust might be built and action undertaken to remedy the multiple health, environmental and sustainable development issues facing millions of people in Ogoni land and beyond. In order to ensure the independence of the study and provide the logistics necessary, a framework for cooperation was negotiated in which all parties were involved and a recognized team of national and international experts then recruited for the two year assessment. [The] report [detailed] how that team carried out their work, where samples were taken and the findings that they made. Over a 14-month period, the UNEP team examined more than 200 locations, surveyed $122 \mathrm{kms}$ of pipeline rights of way, reviewed more than 5,000 medical records and engaged over 23,000 people at local community meetings. Detailed soil contamination investigations were conducted at 69 sites. Altogether more than 4,000 samples were analyzed, including water taken from 142 groundwater monitoring wells drilled specifically for the study and soil extracted from 780 boreholes. The UNEP 'Environmental Assessment report on Ogoni land' was released in August, 2011.”

\subsection{The Findings Of UNEP}

Several findings which were made by UNEP are stated hereunder, in the words of UNEP in the areas of contaminated soil/groundwater, vegetation, aquatic life, public health, institutional issues and oil industry practices etc.

Contaminated Soil and Groundwater: The report concluded that 'pollution of soil by petroleum hydrocarbons in Ogoni land is extensive in land areas, sediments and swampland. Most of the contamination is from crude oil although contamination by refined product was found at three locations. The assessment found that there is no continuous clay layer across Ogoni land, exposing the groundwater in Ogoni land (and beyond) to hydrocarbons spilled on the surface. In 49 cases, UNEP observed hydrocarbons in soil at depths of at least $5 \mathrm{~m}$. This finding has major implications for the type of remediation required. At two-thirds of the contaminated land sites close to oil industry facilities which were assessed in detail, the soil contamination exceeds Nigerian national standards, as set out in the Environmental Guidelines and Standards for the Petroleum Industries in Nigeria (EGASPIN). At 41 sites, the hydrocarbon pollution has reportedly reached the groundwater at levels in excess of the Nigerian standards as per the EGASPIN legislation. The most serious case of groundwater contamination is at Nisisioken Ogale, in Eleme LGA, close to a Nigerian National Petroleum Company product pipeline where an $8 \mathrm{~cm}$ layer of refined oil was observed floating on the groundwater which serves the community wells'.

Vegetation: On vegetation, UNEP found out that 'oil pollution in many intertidal creeks has left mangroves denuded of leaves and stems, leaving roots coated in a bitumen-like substance sometimes $1 \mathrm{~cm}$ or more thick. Mangroves are spawning areas for fish and nurseries for juvenile fish and the extensive pollution of these areas is impacting the fish life-cycle. Any crops in areas directly impacted by oil spills will be damaged, and root crops,

\footnotetext{
${ }^{1}$ See footnote 6 above.

${ }^{2}$ Ibid.

${ }^{3}$ See page 1 of the executive summary of the UNEP report on environmental assessment of Ogoni land cited above.

${ }^{4}$ See pages 9-12 of the executive summary of the UNEP report on environmental assessment of Ogoni land sited above.
} 
such as cassava, will become unusable. When farming recommences, plants generally show signs of stress and yields are reportedly lower than in non-impacted areas. When an oil spill occurs on land, fires often break out, killing vegetation and creating a crust over the land, making remediation or re-vegetation difficult. Channels that have been widened and the resulting dredged material are clearly evident in satellite images, decades after the dredging operation. Without proper rehabilitation, former mangrove areas which have been converted to bare ground are being colonized by invasive species such as nipa palm (which appears to be more resistant to heavy hydrocarbon pollution than native vegetation). In Bodo West, in Bonny LGA, an increase in artisanal refining between 2007 and 2011 has been accompanied by a 10\% loss of healthy mangrove cover, or $307,381 \mathrm{~m} 2$. If left unchecked, this may lead to irreversible loss of mangrove habitat in this area.

Aquatic: The UNEP investigation also found out that 'the surface water throughout the creeks contains hydrocarbons. Floating layers of oil vary from thick black oil to thin sheens. The highest reading of dissolved hydrocarbon in the water column, of 7,420 $\mu \mathrm{g} / 1$, was detected at Ataba-Otokroma, bordering the Gokana and Andoni LGAs. Fish tend to leave polluted areas in search of cleaner water, and fishermen must therefore also move to less contaminated areas in search of fish. When encountered in known polluted areas, fishermen reported that they were going to fishing grounds further upstream or downstream. Despite community concerns about the quality of fish, the results show that the accumulation of hydrocarbons in fish is not a serious health issue in Ogoni land but that the fisheries sector is suffering due to the destruction of fish habitat in the mangroves and highly persistent contamination of many of the creeks, making them unsuitable for fishing. Where a number of entrepreneurs had set up fish farms in or close to the creeks, their businesses have been ruined by an ever-present layer of floating oil. The wetlands around Ogoni land are highly degraded and facing disintegration. The study concludes that while it is technically feasible to restore effective ecosystem functioning of the wetlands, this will only be possible if technical and political initiatives are undertaken'.

Public health: The findings of public health by the same report shows that 'the Ogoni community is exposed to petroleum hydrocarbons in outdoor air and drinking water, sometimes at elevated concentrations. They are also exposed through dermal contacts from contaminated soil, sediments and surface water. Since average life expectancy in Nigeria is less than 50 years, it is a fair assumption that most members of the current Ogoni land community have lived with chronic oil pollution throughout their lives. Of most immediate concern, community members at Nisisioken Ogale are drinking water from wells that is contaminated with benzene, a known carcinogen, at levels over 900 times above the World Health Organization (WHO) guidelines'. The report further stated that this 'contamination warrants emergency action ahead of all other remediation efforts. Hydrocarbon contamination was found in water taken from 28 wells at 10 communities adjacent to contaminated sites. At seven wells the samples are at least 1,000 times higher than the Nigerian drinking water standard of $3 \mu \mathrm{g} / \mathrm{l}$. Local communities are aware of the pollution and its dangers but state that they continue to use the water for drinking, bathing, washing and cooking as they have no alternative. Benzene was detected in all air samples at concentrations ranging from 0.155 to $48.2 \mu \mathrm{g} / \mathrm{m} 3$. Approximately 10 per cent of detected benzene concentrations in Ogoni land were higher than the concentrations WHO and the United States Environmental Protection Agency (USEPA) report as corresponding to a 1 in 10,000 cancer risk. Many of the benzene concentrations detected in Ogoni land were similar to those measured elsewhere in the world, given the prevalence of fuel use and other sources of benzene. However, the findings show that some benzene concentrations in Ogoni land were higher than those being measured in more economically developed regions where benzene concentrations are declining because of efforts to reduce benzene exposure'.

Institutional issues: On institutional issues UNEP stated that 'first issued in 1992, the EGASPIN form the operational basis for environmental regulation of the oil industry in Nigeria. However, this key legislation is internally inconsistent with regard to one of the most important criteria for oil spill and contaminated site' management - specifically the criteria which trigger remediation or indicate its closure (called the 'intervention' and 'target' values respectively). The study found that the Department of Petroleum Resources (DPR) and the National Oil Spill Detection and Response Agency (NOSDRA) have differing interpretations of EGASPIN. This is enabling the oil industry to close down the remediation process well before contamination has been eliminated and soil quality has been restored to achieve functionality for human, animal and plant life. It stated further that 'the Nigerian Government agencies concerned lack qualified technical experts and resources. In the five years since NOSDRA was established, so few resources have been allocated that the agency has no proactive capacity for oil-spill detection. In planning their inspection visits to some oil spill sites, the regulatory authority is wholly reliant on the oil industry for logistical support. The oilfield in Ogoni land is interwoven with the Ogoni community. The fact that communities have set up houses and farms along rights of way is one indicator of the loss of control on the part of the pipeline operator and the government regulator. The UNEP project team observed hundreds of industrial packing bags containing 1,000-1,500 $\mathrm{m} 3$ of waste, believed to be cuttings from oil drilling operations, dumped at a former sand mine in Oken Oyaa in Eleme LGA. The open disposal of such waste in an unlined pit demonstrates that the chain of custody in the region between the waste generator, transporter and disposal facility is not being followed. 
Oil industry practices: The study concludes that the control, maintenance and decommissioning of oilfield infrastructure in Ogoni land are inadequate. Industry best practices and SPDC's own procedures have not been applied, creating public safety issues. Remediation by enhanced natural attenuation (RENA) - so far the only remediation method observed by UNEP in Ogoni land - has not proven to be effective. Currently, SPDC applies this technique on the land surface layer only, based on the assumption that given the nature of the oil, temperature and an underlying layer of clay, hydrocarbons will not move deeper. However, this basic premise is not sustainable as observations made by UNEP show that contamination can often penetrate deeper than $5 \mathrm{~m}$ and has reached the groundwater in many locations. Ten out of the 15 investigated sites which SPDC records show as having completed remediation, still have pollution exceeding the SPDC (and government) remediation closure values. The study found that the contamination at eight of these sites has migrated to the groundwater. In January 2010, a new Remediation Management System was adopted by all Shell Exploration and Production Companies in Nigeria. The study found that while the new changes are an improvement, they still do not meet the local regulatory requirements or international best practices.

\subsection{The Hydrocarbon Remediation Project Report (HYPREB) On The Ogoni Environment Of Nigeria, its} Establishment, Functions, Achievements and Perceptions ${ }^{1}$

HYPREP was established under the Federal Ministry of Environment ${ }^{2}$ to achieve the under listed objectives in Ogoni land and other impacted communities:

1. Determine the scope, means and modalities of remediation of soil and ground water contamination in impacted communities as maybe recommended by HYPREP Governing Council and remedy them.

2. Enhance local capacity for better environmental management and promote awareness of sound environmental management as well as ensure livelihoods and sustainable development.

3. Ensure security and promote peace building efforts in impacted communities.

4. Strengthen governance, transparency and accountability in the region.

5. The HYPREP established the project coordinating office, a governing Council and board of trustee with an operative office at No. 350 Aba Road, Port-Harcourt, Rivers State Nigeria.

\section{The Functions of HYPREP ${ }^{3}$}

The functions of HYPREP as shown in the instrument cited above include the following:

i. Investigate, map and evaluate hydrocarbon polluted communities and sites in Nigeria referred to it by the National Oil Spill Detection Response Agency (NOSDRA) or the Federal Ministry of Environment in collaboration with the Department of Petroleum Resources (DPR) and make recommendations to the Federal government.

ii. Implement the recommendations of the United Nations Environment Programme (UNEP) Report on Environmental Restoration of Ogoni land (UNEP Report) as directed by the HYPREP Governing Council.

iii. Initiate, and develop work programmes aimed at restoring all hydrocarbon impacted communities and sites referred to HYPREP.

iv. Undertake a comprehensive assessment and mapping of all environmental issues associated with hydrocarbon pollution, in collaboration with NOSDRA.

v. Provide guidance data to undertake remediation of contaminated soil and ground water in Ogoni land and such other impacted communities as may be referred to it.

vi. Technically evaluate alternative technologies to be employed to undertake remediation of contaminated soil and ground water.

vii. Make recommendations for responding to future environmental contamination from hydrocarbons.

viii. Ensure full environmental recovery and restoration of Ogoni ecosystem services for Ogoni people and other impacted communities.

\section{ACHIEVEMENTS OF HYPREP TO DATE ${ }^{4}$}

a) Project Activities: To ensure proper Stakeholder participation in the Programme, four (4) Ad hoc Committees were inaugurated on 24 May 2016 to commence preparation for activities on the clean-up project. Each committees had 16 members drawn from all the local governments in Ogoni land communities. The committee are:

1. Committee for the Centre of Excellence and the Integrated Contaminated Soil Management Centre.

2. Committee for Training and Livelihood.

3. Committee on Communication and Strategy.

\footnotetext{
${ }^{1}$ See www.hyprep.gov.ng, accessed on the $11^{\text {th }}$ day of October, 2018.

${ }^{2}$ As published in the Federal Government gazette No. 176, Vol. 103 of December, 2016

${ }^{3}$ Ibid.

${ }^{4}$ Ibid
} 
4. Committee on Emergency Measures. The above committees setup by HYPREP submitted their reports on 2nd September 2016.

On 16th February, 2017 the ground-breaking ceremony for the construction of the Integrated Contaminated Soil Management Centre in Bori New City in Khana Local Government Area of Ogoni land and the project for Demonstration of Clean-up Technology was also launched at a site in Kwawa, Khana Local Government Area of Ogoni land, with demonstration projects also starting at eleven (11) other sites identified in the four Local Government Areas of Ogoni land. It is submitted at this point that the various committee setup by HPREP do not appear to have the capacity or the required finances to enable them carry out the functions they are created to serve. Furthermore it shows the lack of political will, on the side of the Federal Government of Nigeria to implement the UNEP report which formed the bases, for the setting up of HYPREP in Ogoni land.

However, Rivers State Government Nyesom Wike has said that "the protracted implementation of the United Nations Environment Programme (UNEP) report on Ogoni is a grand fraud and deception. Wike, who made this assertion while addressing the 108 and 109 general session of Rivers State Council of Traditional Rulers in Port Harcourt, urged monarchs in the state to lend their voices in condemning the neglect or Rivers State by the Federal Government. He said it was disheartening that 28 months after the Federal Government launched the Ogoni land clean-up, they were yet to commence the exercise as recommended by UNEP. According to him, it was time the people lent their voices more forcefully to the neglect of the state by the Federal Government, the devastation of the environment by the oil companies, the grand fraud and deception in the Ogoni clean-up exercise and the call for economic justice and fiscal federation. In addition he also said that the state owned security outfit, Rivers State Neighbourhood Safety Agency, would soon commence operation for the primary purpose of detection and prevention of crimes across the state." 1

\section{Emergency Measures Recommended by UNEP Report On Ogoni Land ${ }^{2}$}

The report identifies eight emergency measures which, from a duty of care point of view, warrant immediate action.

1. Ensure that all drinking water wells where hydrocarbons were detected are marked and that people are informed of the danger.

2. Provide adequate sources of drinking water to those households whose drinking water supply is impacted.

3. People in Nsisioken Ogale who have been consuming water with benzene over 900 times the WHO guideline are recorded on a medical registry and their health status assessed and followed up.

4. Initiate a survey of all drinking water wells around those wells where hydrocarbons were observed and arrange measures (1-3) as appropriate based on the results.

5. Post signs around all the sites identified as having contamination exceeding intervention values warning the community not to walk through or engage in any other activities at these site.

6. Post signs in areas where hydrocarbons were observed on surface water warning people not to fish, swim or bathe in these areas.

7. Informed all families whose rainwater samples tested positive for hydrocarbons and advised them not to consume the water.

8. Mount a public awareness campaign to warn the individuals who are undertaking artisanal refining that such activities are damaging their health.

b) Emergency Measures Reportedly Undertaken By HYPREP In Ogoni Land ${ }^{3}$

1. Water: The report by HYPREP showed that the body, did setup a four man committee on Water to identify and evaluate existing water facilities in the four local government areas of Ogoni. The said report was turned in reportedly after a thorough and painstaking tour of those water facilities in Ogoni land. The report revealed obsolete and abandoned water infrastructure and the quality of water from some functioning facilities do not meet the WHO potable water requirements.

2. Updates of Baseline Data of UNEP Report: The UNEP report was submitted to the Federal Government in 201 land between then and now, there have been changes in the nature and characteristics of the impacted sites that were studied in the report. In addition, there have been other impacted sites that were not captured in the UNEP report. In collaboration with UNEP, we are about to commence the process of scoping and updating all sites previously assessed including newly impacted sites and others not previously captured by UNEP in Ogoni land.

3. Health Impact Assessment Study: One of the other key recommendations by the UNEP report is the conduct of a health impact study in the impacted communities of Ogoni to ascertain whether there is a link between some disease pattern and oil pollution in the community. In this regard we had on 10th July, 2017 advertised in some Nigerian dailies for the expression of interest and invitation for the pre-qualification for the implementation

\footnotetext{
${ }^{1}$ See The Guardian, Tuesday, November 6, 2018, P.15

${ }^{2}$ See page 13 of the executive summary of the UNEP reports on environmental assessment of Ogoni land.

${ }^{3}$ Ibid.
} 
Health Impact Assessments, Immediate assessment and carrying out the rehabilitation of existing water facilities in Ogoni land, Design and construction of comprehensive water schemes in Ogoni land and Environmental Consultancy to carry out Scoping and assessment of oil impacted sites assessed by UNEP in Ogoni land. The bids were opened on Monday 24, July 2017. A total number of Two Hundred and Three (203) bids were received and opened. We are partnering with the UN system especially WHO in this regard.

4. Medical Outreaches:

a. Over 3,000 Ogoni indigenes have benefited from the free medical outreach organised by the Hydrocarbon Pollution Remediation Project, (HYPREP).The HYPREP Coordinator, Dr. Marvin Dekil, said the health outreach was significant to the clean-up exercise in Ogoni land.

b. That the HYPREP has reportedly carried out two phases of medical intervention in four Local Government Areas of Ogoni land in the year 2016 and those who were diagnosed with painful but treatable medical conditions due to limited access to health facilities and lack of finances were treated by the medical team and that the process of the clean-up has been consistent, that we are suppose - to do within the law but expressed the hope that a review on the operations and that emergency measures like the provisions of water, have being opened and more demonstration project sites, health impact assessment have also been carried out among others. ${ }^{1}$

5. The Way Forward And Recommendations Made By United Nations Environmental Programme $(\mathrm{UNEP})^{2}$

Restoring the livelihoods and wellbeing of future Ogoni generations is within reach but timing is crucial. Given the dynamic nature of oil pollution and the extent of contamination revealed in UNEP's study, failure to begin addressing urgent public health concerns and commencing immediate cleanup will only exacerbate and unnecessarily prolong the Ogoni people's suffering. A Transition Phase is recommended to maintain momentum and begin detailed planning in the intervening period between the release of UNEP's environmental assessment and the commencement of a clean-up operation guided by an Ogoni land Environmental Restoration Authority.

\section{CONCLUSION}

This paper has attempted to carry out an appraisal of some critical highlights of the United Nations Environment Programme Report (UNEP) on the environmental assessment of Ogoni land, the setting up of the Hydrocarbon Remediation Project (HYPREP) by the Federal Government of Nigeria, its operations and some recommendations towards creating a sustainable environment and development in Ogoni land.

There is no doubt that a lot has gone wrong in Ogoni land particularly and the Niger Delta region, generally. For sustainable development, justice for Nigeria to know equity and peace to reign, Nigeria must quickly implement the UNEP report it is worthy of note that, the Buhari - led Federal Government of Nigeria appropriately approved the setting up of a board of trustees to commence the process of implementing the report and approval of the amendment of the Official Gazette establishing the Hydrocarbon Pollution Restoration Project (HYPREP), to reflect a new governance framework and a new implementation template. But more need to be done and ought to be done now.

\section{RECOMMENDATIONS}

1. It is, however, worth stressing that Ogoni land merely represents an entry point on the issue of environmental degradation caused by oil exploration and exploitation in the Niger Delta. It is contended that the entire Niger Delta requires restoration.

2. While focusing on Ogoni land, the President of the Federal Republic of Nigeria should also initiate a comprehensive framework, more than only setting up the HYPREP to clean up the entire Niger Delta where the oil producing communities have been devastated by oil spills.

3. To this end, the only lasting solution is genuine federalism. Peoples of different regions should take full control of the resources in their domain and pay tax or royalties to the Federal Government. Though some feeble attempts have been made in the past to bring succour to the Niger Delta without sustainable success.

4. The Federal Republic of Nigeria is called upon to work towards bringing about environmental sustainability and development by urgently implementing the UNEP report, without further delay before the Ogoni people and others in the Niger Delta regions before they are completely wiped out due to avoidably epidemics contacted in the environment of the region due to the degradation of the environment arising from oil/gas operations.

5. The international community must put pressure on the Government of Nigeria to do a thorough clean-up that meets international standards within the timelines set by UNEP.

6. It is worrisome that since Nigeria's former Minister of Environment and current Deputy Secretary General of

\footnotetext{
${ }^{1}$ Ibid.

${ }^{2}$ See page 17 of the executive summary of the UNEP reports on environmental assessment of Ogoni land cited above.
} 
the United Nations, Amina Muhammed, in February 2017 laid a foundation for the commencement of the UNEP report, the project has been abandoned and the site in Bori currently overgrown with weeds. This situation must change.

7. To the ordinary Ogoni man, the implementation of the UNEP report constitute the activities of HYPREP majorly characterized by talking rhetorics and showing pictures without concrete evidence on works about the project and that 'HYPREP is just going round organising workshops and taking pictures, while the environment is still left suffering, no more fish, periwinkle --- is there no clear package in the clean up? HYPREP is talking too much rhetorics, nothing is being done, is there no need for state of emergency in the area because things need to be done urgently'.

8. It is further recommended that the Federal Government of Nigeria, quickly tackle the major challenge of the agency, which seems to be, the inability to access fund directly from the Federal government.

9. In the interim, the Civil Society Legislation Advocacy Centre (CISLAC) has sought for an Act to back up the activities of Hydrocarbon Pollution Remediation Project (HYPREP) through independence legislation that would allow for more robust and comprehensive engagement in the cleaning of Ogoni land.

10. Government as an administration and oil firms should, as a matter of urgency, start the decommissioning of oil facilities in Ogoni ahead of the clean-up to prevent re-pollution that might cause a hindrance or setback to the entire operation/movement. In addition a dedicated CSO desk should be established to interface with the larger public and profile feedbacks as a panacea for a sustainable remediation process. 